\title{
VOLUME CHANGE BEHA VIOUR OF BANTING CLAY BY THE CONCEPT OF EFFECTIVE STRESS AND SHEAR STRENGTH INTERACTION
}

\author{
(Date received: 28.11.2019/Date accepted: 08.07.2020) \\ Syahmizzi Ifwat Bin Azharnim¹, Mohd Jamaludin Md. Noor ${ }^{2}$ \\ ${ }^{1}$ Minconsult Sdn. Bhd., Petaling Jaya, 46100 Malaysia \\ ${ }^{2}$ Faculty of Civil Engineering, Universiti Teknologi MARA, Shah Alam, 40450 Malaysia \\ Email: syahmizzi.azharnim@minconsult.com,mohdjamaludinmdnoor@yahoo.com
}

\begin{abstract}
Effective stress and shear strength interaction which the stress - strain curves and mobilised shear strength envelope explained the actual volume change behaviour of the soils. The interaction that useful in prediction of stress - strain curves and unique relationship between Effective Mobilised Minimum Friction Angle and Axial Strain is important to predict the settlement at any effective stresses include the effective stress that not conducted in laboratory test. Consolidated drained triaxial test is conducted for saturated Banting CLAY and the volume change behaviour of Banting CLAY is presented from the concept of effective stress and shear strength interaction with the establishment of unique relationship between effective mobilised minimum friction angle with respect to axial strain and prediction of stress - strain curves for the saturated Banting CLAY.

Keywords: Non-linear Shear Strength, Rotational Multiple Yield Surface Envelope, consolidated drained triaxial tests, shear strength interaction, banting clay.
\end{abstract}

\subsection{INTRODUCTION}

Many geotechnical structures and works such retaining wall, soil slope, foundation, road base and others are depending on the shear strength and behaviour of soil. Theoretically, the geotechnical problem especially settlement is using the settlement model that are only based on the effective stress concept. The shear strength of the soil shall also influence the volume change behaviour of the soil. Settlement or volume change behaviour of soils that takes into consideration on both effective stress and shear strength is introduced by M.J. Md Noor et al. (2010) in the Rotational Multiple Yield Surface Framework (RMYSF) that can explained the concept of the effective stress and shear strength interaction. Based on this model, a study has been conducted on saturated Banting CLAY to observe the volume change behaviour from the consolidated drained triaxial test. The prediction of stress - strain curve and unique relationship between the effective mobilised minimum friction angle, $\varphi_{{ }^{\prime}{ }^{\prime} n_{m o b}}$ and axial strain, $\boldsymbol{\varepsilon}$, has been developed. The banting CLAY formation and condition are discussed further in section 3 below.

The main objectives of this study as below:

i. to determine the failure shear strength envelope of Banting CLAY using Drained Triaxial Compression Test.

ii. to determine the anisotropic volume change behaviour of Banting CLAY

iii. to investigate the mobilize shear strength envelope and relationship between effective mobilized minimum friction angle and axial strain of Banting CLAY

iv. to illustrate the consolidation settlement calculation based on the effective stress and shear strength concept by Rotational Multiple Yield Surface Framework (RMSFY).

\subsection{EFFECTIVE STRESS CONCEPT AND SHEAR STRENGTH INTERACTION}

Settlement can be triggered by increase of effective stress due to the reduction of pore water pressure or increase in loading or total stress. However, the increase in pore water pressure due to the reduction of suction that results to the reduction of shear strength also will trigger the settlement (M.J. Md. Noor $e t$ al., 2010). Therefore, the concept of effective stress and shear strength interaction is the best concept to explain the settlement phenomenon with regards to increase in effective stress or reduction of shear strength of the soil.

This study is to determine the volume change behaviour of the saturated Banting CLAY. According to RMYSF model (M.J. Md. Noor et al, 2014), the Mohr-Circle for saturated soils is located at the net stress axis where there is no suction in the soils body. According to O.K Nusier et al. (2008), at very low stress level, the non-linear behaviour is prudent. The accurate resemblance of stress-strength behaviour is most needed when material properties need to be predicted on analysed at very low stress which the shear strength envelope of the material is tend to non-linear behaviour.

The mobilised shear strength envelope is developed and rotated towards failure state due to the compression on the soils. The mobilised envelope presented as non-linear shear strength envelope where the envelope intercept at origin. The effective mobilised minimum friction angle, $\varphi_{\min _{m o b}}^{\prime}$, which increases as the soil undergo compression shows the soils volume change behaviour as anisotropic soils behaviours.

The mobilised shear strength envelope increases due to the compression on the soils or also indicated as consolidation 


\section{VOLUME CHANGE BEHAVIOUR OF BANTING CLAY BY THE CONCEPT OF EFFECTIVE STRESS AND SHEAR STRENGTH INTERACTION}

settlement. When the settlement completed, the mobilised shear strength will stop rotating towards the failure state. The soil particles will be closer named as soil hardening. When the soil is in stress equilibrium state, the shear strength will equal to the applied stress (Hara et al., 1974). The rotation of the mobilised shear strength before reaching the shear strength at failure represent the volume change behaviour of the soil according to the concept of effective stress and shear strength interaction. The rotation of the mobilised shear strength that result in increment of effective mobilised minimum friction angle, $\varphi_{\min _{m o b}}^{\prime}$ can developed a unique relationship with respect to the axial strain that is useful in prediction of the consolidation settlement. The prediction of settlement based on this concept will be the settlement that associated with both effective stress and shear strength.

Based on classical theory, the settlement model has no relation with shear strength. However, the concept of effective stress and shear strength interaction is concept to predict settlement that associated with both effective stress and shear strength of the soil.

\subsection{BANTING CLAY AS STUDIED SOIL}

Soil is a discrete particle in form of mineral composition and sometimes contains organic which includes air and water. Soils can be separated by gentle mechanical means. (BS 1377, 1990).

Clay is cohesive soils where it is soil that forms a coherent mass because of its fine-grained content. Banting CLAY which collected at site is classified as Silty CLAY that rich of moisture contents, liquid limit that mostly more than $80 \%$ and easily to mould. The soil samples taken at Kampung Medan, Banting, Klang which commonly is Palm Oil Plantation Area.

The site location is generally underlain by Quaternary Alluvium. Alluvium deposit at this area generally consists of marine and continental deposits such as clay, silt, sand, peat with minor gravel. Based on the Lee et al. (2004), This quartenary alluvium consists of Gula Formation, Beruas Formation and Simpang Formation. Gula Formation is subdivided into two members, Port Weld Member and Matang Gelugor Member. Lithology of Port Weld member consists of clay and silt, locally very clayey or silty sand. Meanwhile, the Matang Gelugor Member consists of sand locally gravelly. Both members are deposited in the littoral, estuarial and shallow sea environment at the epoch of Holocene.

Beruas Formations is unit comprises unconsolidated, fluvial, and lacustrine deposits and swamp peats, usually limited to positions adjacent to present-day streams (A.B Daud, 2015). The term Pengkalan Member was introduced for the inland freshwater swamp deposit which is made up of clay, peat and silt. It has same epoch with the previous Gula formation, Holocene.

The last formation Simpang Formation which is deposited in the epoch of Holocene and Pleistocene, the youngest of quaternary period. This formation characterized by clay, silts and gravel overlying granitic rock and deposited in the terrestrial environment. This formation is subdivided into two members, the Lower Sand Member which is consists of sand and gravel and the Upper Clay Member which is mainly clay. The thickness varies from a few meters to more than $50 \mathrm{~m}$.

Furthermore, few locations or soils have been studied for the same purposes (non-linear shear strength and/or volume change behaviour) except for Banting CLAY. Most of the previous research focused on the tropical residual soil such Granitic
Residual Soil and Koalin CLAY (M.J. Md. Noor and B.A Hadi, 2010), Granitic Residual Soil VI (M.J. Md. Noor and A. Derahman, 2011), silty clay SAND (O.K. Nusier et al., 2008), Blue Mountain Limestone GRAVEL (I.B. Mohamed Jais \& M.J. Md. Noor, 2009), Tanjung Bin Soft CLAY (I.B. Mohamed Jais \& M.J. Md. Noor, 2009) and unsaturated granitic residual soil (M.J. Md. Noor and I.B. Mohamed Jais, 2014).

Based on the Banting CLAY properties and geological formation explained above as well as the gap of research, the banting CLAY has been choose for the study of volume change behaviour of soil with regards to effective stress and shear strength concept.

In this study, the Banting CLAY is tested by Consolidated Drained Triaxial Test at effective stress 50, 100, 200 and 300 $\mathrm{kPa}$. The consolidated drained triaxial test is used to determine the shear strength at failure for the Banting CLAY, mobilised shear strength envelope, volume change behaviour as well as the unique relationship between the effective mobilised minimum friction angle and axial strain. The Consolidated Drained Triaxial Test have been carried out based on the BS 1377 (1990). Figure 1 and Figure 2 below shows the triaxial test equipment set up for this study and the specimen upon completion of the drained triaxial test.

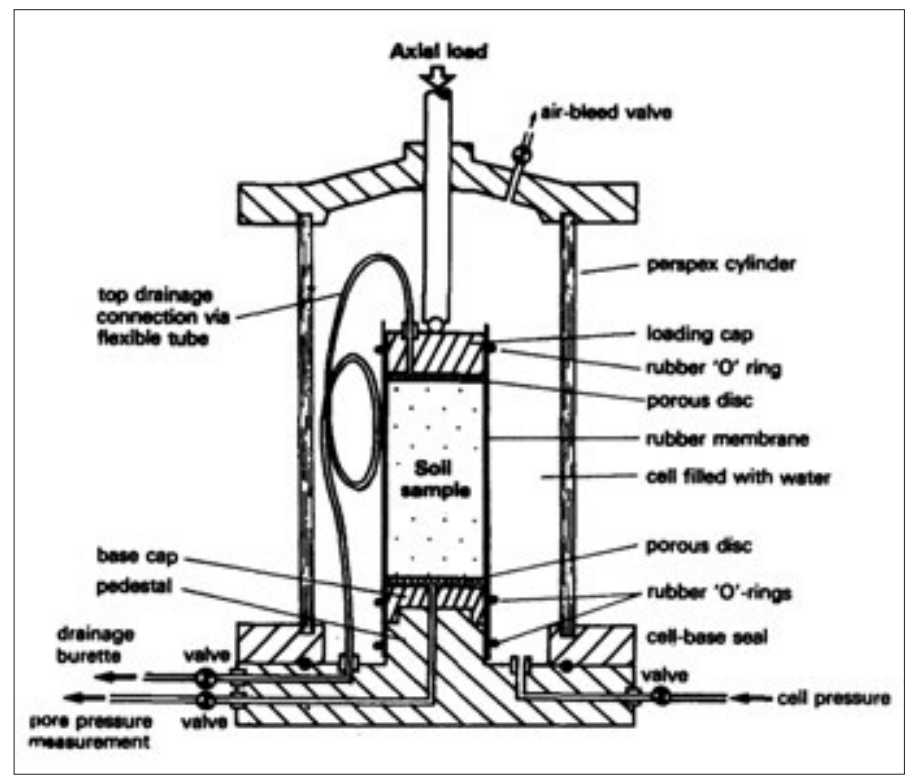

Figure 1: Triaxial test equipment set up (R. Withlow, 2004)

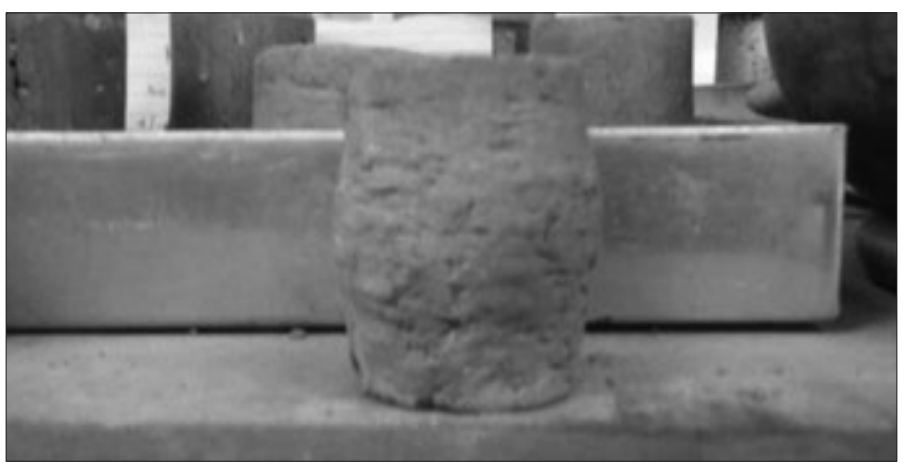

Figure 2: Specimen upon completion of triaxial test

Figure 2 above, shows the plastic yield failure mode on the Banting CLAY specimen which can illustrate the volume change behaviour of the Banting CLAY. Generally, plastic yield failure 
produced barrel shaped appearance when the axial load reached the peak stress. The normally consolidated soils will experienced this type of failure where no formation of slip surface present especially in settlement phenomenon (R.Withlow, 2004).

\subsection{MOBILISED SHEAR STRENGTH FAILURE ENVELOPE}

Based on the consolidated drained triaxial shear strength, the stress - strain relationship for the Banting CLAY as shown in Figure 3 below:

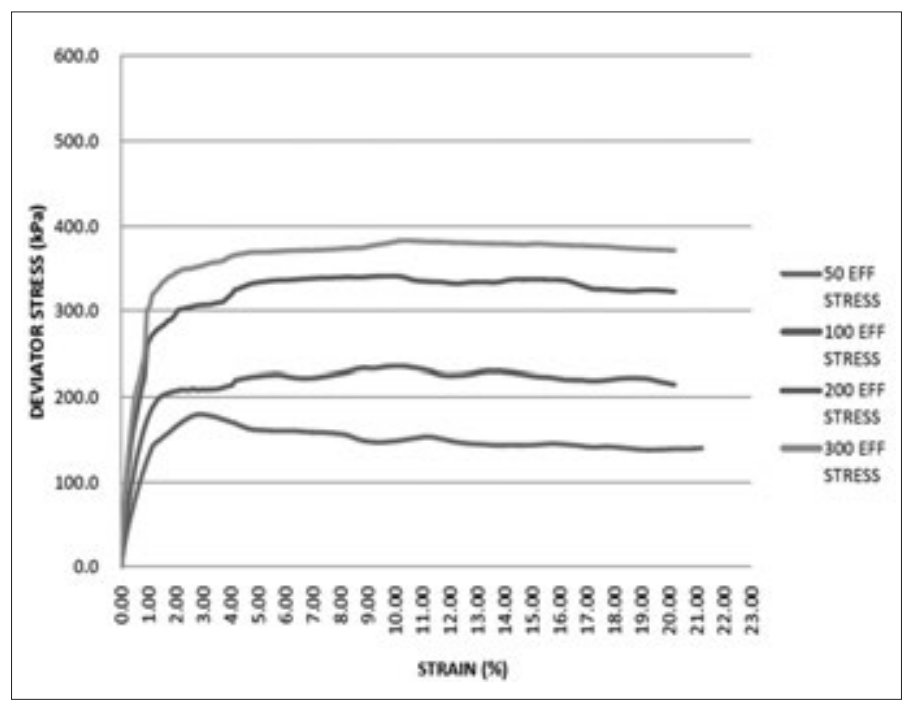

Figure 3: Stress - Strain Relationship of Banting CLAY

With reference to Figure 3 above, few data are obtained. Mobilize shear strength envelope can be plotted by plotting Mohr Circle and Shear Strength Envelope based on the effective stresses and deviator stress. Deviator Stress from selected axial strain until it reached the axial strain at failure is obtained from Figure 3 above. Since the specimen fail at axial strain of $4 \%$, the deviator stress is selected at axial strain of $0.2,0.5,0.75,1$, 2,3 and $4 \%$ for all 50, 100, 200 and $300 \mathrm{kPa}$ effective stresses for this study. Table 1 as shown below is the Deviator Stress obtained from the Banting CLAY stress - strain relationship.

Table 1: Deviator Stress at each Mobilized Axial Strain

\begin{tabular}{|c|c|c|c|c|}
\hline \multirow{2}{*}{$\begin{array}{c}\text { Axial } \\
\text { strain } \\
(\%)\end{array}$} & \multicolumn{4}{|c|}{ Effective Stress (kPa) } \\
\cline { 2 - 5 }$(\boldsymbol{\%})$ & 50 & 100 & 200 & 300 \\
\hline 0.2 & 38.6 & 57.4 & 95.6 & 110.2 \\
\hline 0.5 & 75.3 & 112.3 & 165.6 & 195.4 \\
\hline 0.75 & 107.7 & 153.0 & 210.9 & 234.5 \\
\hline 1.0 & 125.7 & 173.0 & 258.0 & 300 \\
\hline 2.0 & 164.9 & 206.6 & 296.0 & 345.1 \\
\hline 3.0 & 179.1 & 208.7 & 306.9 & 353.9 \\
\hline 4.0 & 170.9 & 213.3 & 317.5 & 363.2 \\
\hline
\end{tabular}

According to RMYSF model, the failure envelope will intercept at the origin and developed the curve line envelope at very low stresses. With reference to deviator stress obtained above, the shear strength failure envelope for saturated Banting CLAY is shown as in Figure 4 below.

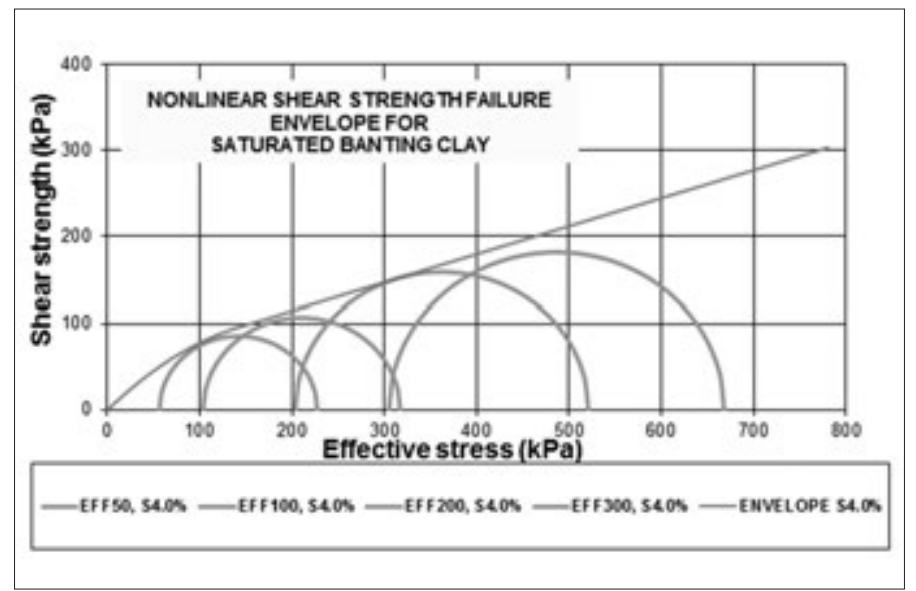

Figure 4: Nonlinear Shear Strength Failure Envelope of Banting CLAY

The shear strength in RMYSF can be determined by equation (1), (2) and (3) below:

$$
\begin{aligned}
& \tau_{F}=\frac{\left(\sigma-u_{w}\right)}{\left(\sigma-w_{w}\right)_{t}}\left[1+\frac{\left(\sigma-u_{w}\right)_{t}-\left(\sigma-w_{w}\right)}{N\left(\sigma-w_{w}\right)_{t}}\right]
\end{aligned}
$$

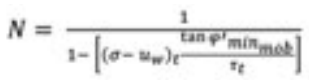

$$
\begin{aligned}
& \tau_{f}=\left(\sigma-u_{w}\right) \tan \varphi_{\min _{m a b}}+\left[\tau_{t}-\left(\sigma-u_{w}\right)_{t} \tan \varphi_{\text {min }_{\text {most }}}^{\prime}\right]
\end{aligned}
$$

Where :

$\left(\sigma-u_{w}\right)=$ Net Stress/Effective Stress

$\left(\sigma-u_{w}\right)_{h}=$ Transition Effective Stress

$\tau_{\mathrm{t}} \quad=$ Transition Shear Strength

$\varphi^{\prime}{ }_{m i n_{m o s}}=$ Effective Mobilized Minimum Friction Angle According to Figure 4 above, the shear strength parameter at failure for RMYSF model are $140 \mathrm{kPa}$ of transition effective stress, $97.0 \mathrm{kPa}$ of transition shear strength and $18^{\circ}$ of effective minimum failure friction angle.

Further to data shown in Table 1 above, the mobilised shear strength at axial strain of $0.2,0.5,0.75,1.0,2.0,3.0$ and $4.0 \%$ are plotted as shown in Figure 5 below:

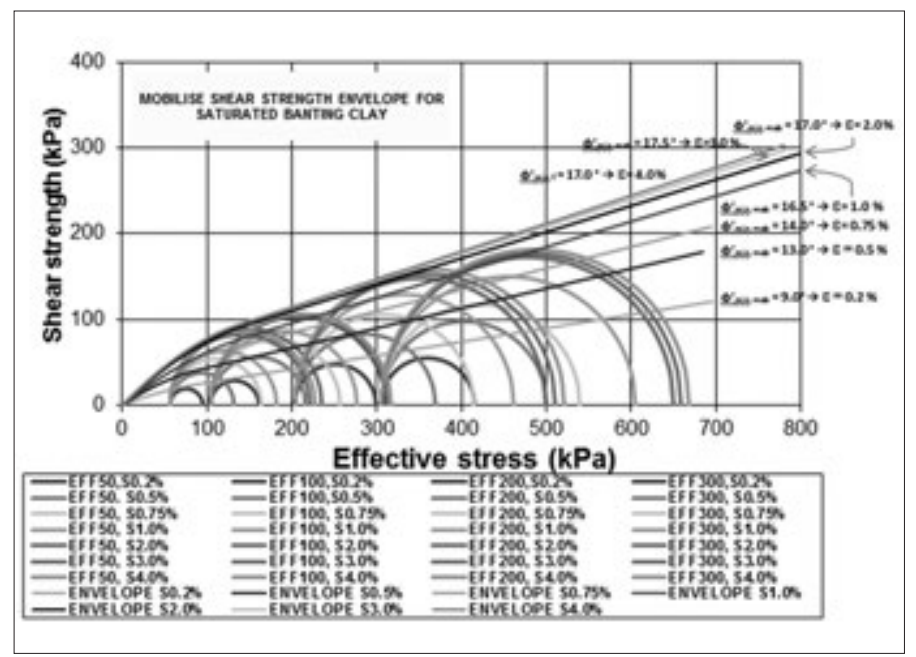

Figure 5: Mobilized Nonlinear Shear Strength Envelope of Saturated Banting CLAY

The stress-strain relationship of soil is important and useful in prediction of settlement. The concept of stress-strain prediction from determination of deviator stress in the mobilized 


\section{VOLUME CHANGE BEHAVIOUR OF BANTING CLAY BY THE CONCEPT OF EFFECTIVE STRESS AND SHEAR STRENGTH INTERACTION}

shear strength envelope as in Figure 5 above will assist in the prediction of the settlement at any effective stresses include the effective stresses that are not conducted in laboratory.

As discussed before, consolidated drained triaxial tests are conducted only for effective stresses of 50, 100, 200 and $300 \mathrm{kPa}$. The prediction of stress-strain relationship for effective stress $150 \mathrm{kPa}$, which not conducted in laboratory, can be determined as in Figure 6 below:

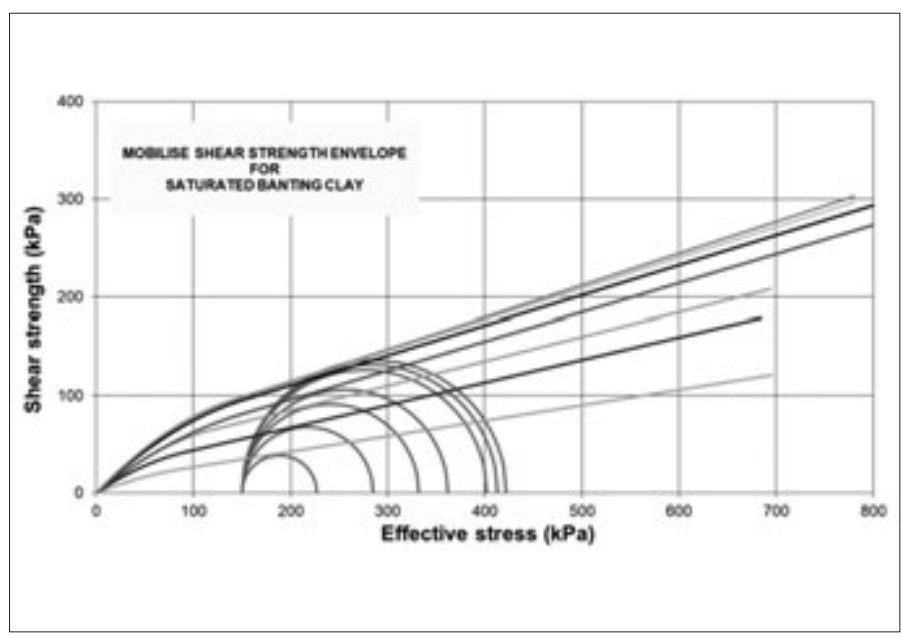

Figure 6: Deviator Stress Determination for Stress-strain Curves Prediction at 150kPa Effective Stress

Based on the deviator stress predicted in mobilized shear strength envelope as shown in Figure 6 above, the stress-strain curve for $150 \mathrm{kPa}$ Effective Stress as plotted in Figure 7 below:

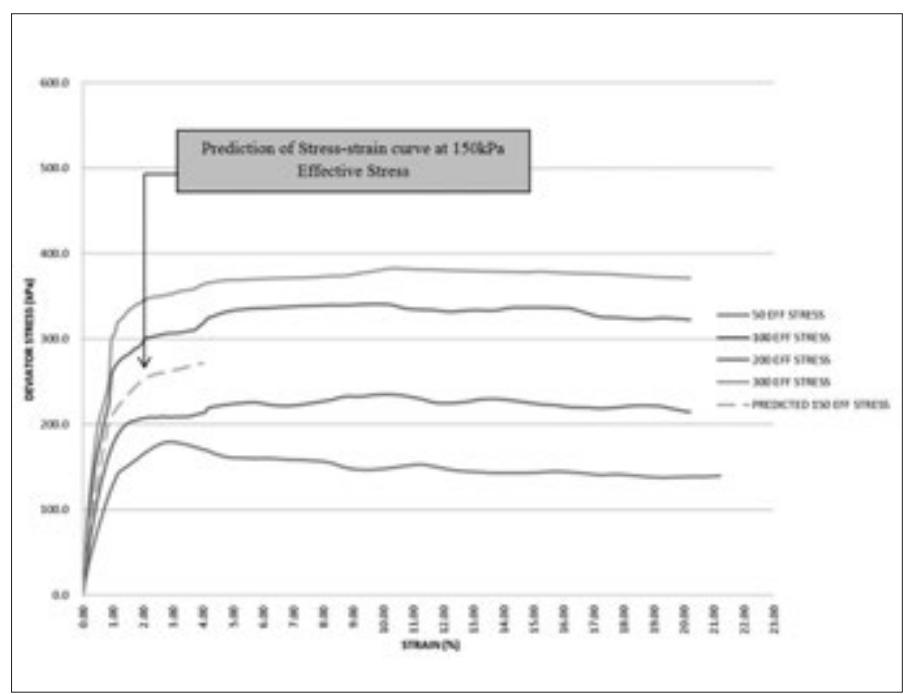

Figure 7: Prediction of Stress-strain Curve at Effective Stress that not conducted in Laboratory (Effective Stress $=150 \mathrm{kPa})$

\subsection{RELATIONSHIP BETWEEN EFFECTIVE MOBILISED MINIMUM FRICTION ANGLE AND AXIAL STRAIN OF SATURATED BANTING CLAY}

Effective Mobilized Minimum Friction Angle versus Axial Strain is unique due to its relationship that can be used in any effective stresses which include the predicted effective stresses where no triaxial test conducted in the laboratory.
Table 2 below shows the effective mobilised minimum

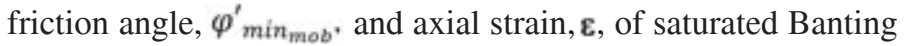
CLAY obtained from the mobilised nonlinear shear strength envelope as shown in Figure 5 above.

Table 2: Axial Strain and Effective Mobilized Minimum Friction Angle of saturated Banting CLAY (Excerpt from Figure 5)

\begin{tabular}{|c|c|}
\hline Axial strain (\%) & $\begin{array}{c}\text { Effective Mobilized Minimum } \\
\text { Friction Angle }\left({ }^{\circ} \text { ) }\right.\end{array}$ \\
\hline 0.2 & 9.0 \\
\hline 0.5 & 13.0 \\
\hline 0.75 & 14.0 \\
\hline 1.0 & 16.5 \\
\hline 2.0 & 17.0 \\
\hline 3.0 & 17.5 \\
\hline 4.0 & 18.0 \\
\hline
\end{tabular}

Based on the data obtained, the unique relationship plotted in Effective Mobilized Minimum Friction Angle against Axial Strain as shown in Figure 8 below:

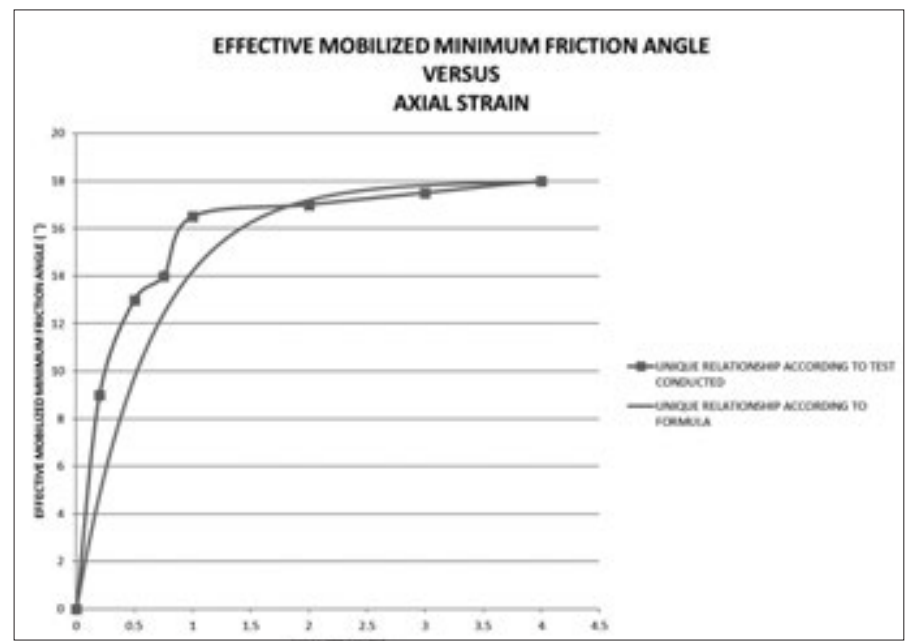

Figure 8: Unique Relationship between Effective Mobilized Minimum Friction Angle with respect to Axial Strain of saturated Banting CLAY

The unique relationship between effective mobilized minimum friction angle and axial strain based on formula by MOHAMED JAIS ET AL. (2009) as equation (4) below:

$$
\varphi_{\min m o b}^{\prime}=\varphi_{\min f}^{\prime}\left(1-e^{-A \varphi_{a}}\right)
$$

Where $\varphi_{\min }^{\prime}$ is the effective mobilised minimum friction angle, $\varphi_{\min _{m o b}}^{\prime}$ is effective minimum friction angle at failure, $\Omega$ is soil coefficient of anisotropic compression and $\varepsilon_{\mathrm{a}}$ is axial strain of saturated Banting CLAY. Hence, the $\Omega$ for the Banting Soil is 1.558 which calculated based on equation (4) from $\varphi_{\min _{m o b}}^{\prime}, \varphi_{\min f}^{\prime}$, and $\varepsilon_{\mathrm{a}}$ obtained from the triaxial tests.

All classical theories regarding to the settlement are only related to the effective stress concept. Settlement that relate to the volume change behaviour and shear strength of the soil has never been explored. By using these mobilize shear strength and unique relationship between effective mobilise minimum friction angle with corresponding to axial strain, the settlement can be predicted by the Equation (5) and (6). 
Settlement, $=\Delta \mathrm{a}_{\mathrm{x}} \mathrm{\text {Layer }}$ Thickness

$\Delta \mathrm{\varepsilon}_{\mathrm{a}}=\mathrm{zar}-\mathrm{\varepsilon ai}$

Where $\quad \Delta \varepsilon=$ difference in strain

zar $=$ Strain at Final Stress State

$\varepsilon a i=$ Strain at Initial Stress State

The Strain at final and initial stress state can be obtained from the unique relationship as shown in Figure 7 above at any required effective and/or deviator stress. The Effective Mobilize Minimum Friction Angle is obtained from the Mobilize Nonlinear Shear Strength Envelope as shown in Figure 5. These two (2) graphs are related to each other for predicting the settlement at current stress state of the soils.

\subsection{CONCLUSIONS}

Based on the results obtained from the Drained Triaxial Compression Test on Banting CLAY at effective stress 50, 100, 200 and $300 \mathrm{kPa}$ and the items discussed above, this study can be concluded as below:

i. Consolidation settlement can be predicted based on the effective stress and shear strength concept by drained triaxial test instead of classical theories which only related to effective stress. However, this study is not covering on the consolidation settlement rate.

ii. The relationship between effective mobilized minimum friction angle versus axial strain is unique because it applicable to any effective stresses including the required effective stresses which the tests are not conducted in laboratory and can be predicted as illustrate in section 4 above. This unique relationship can be used for predicting the consolidation settlement at any effective stresses.

iii. Based on this study, the consolidation settlement that related to soil volume change behaviour is explored. The settlement can be calculated by difference of axial strain, which obtained from relationship of effective mobilized minimum friction angle versus axial strain, multiply with the layer of thickness.

\section{REFERENCES}

[1] Md.Noor, M. J. and B.A. Hadi, "The role of curves-surface envelope Mohr-Coulomb model in governing shallow infiltration induced slope failure", EJGE, 1-21, 2010.

[2] O.K. Nusier, I.M Almohd, and Jaradat, "Nonlinearity of shear strength and stress-strength behavior and induced stress prediction", ICCBT2008, 1-10, 2008

[3] I.B. Mohamed Jais and M.J Md. Noor, "Establishing Unique Relationship between Minimum Mobilised Friction Angle and Axial Strain for Anisotropic Soil Settlement Model", Asia pacific Conference on Unsaturated Soil New Castle, Australia, 2009.

[4] M.J. Md. Noor and I.B. Mohamed Jais, "Prediction of stress strain response by rotational multiple yield surface framework for unsaturated granite residual soil", Unsaturated Solis : Research \& Application, London, 2014.

[5] S.K. Kong and D.Q. Yang, "Shear strength characteristics of residual soils from sedimentary Jurong formation in Singapore", 13th Southeast Asian Geotechnical Conference, 16-20 November. 1998, Taipei, Taiwan, ROC, 1-7, 1998.

[6] M.J. Md.Noor and A. Derahman, "Curvi-linear shear strength envelope for granitic soil grade VI", Unsaturated Soils: Theory and Practice 2011, 1-6, 2011.

[7] Hara, "Shear Modulus and Shear Strength of Cohesive Soils", Japanese Society of Soil Mechanic and Foundation Engineering. Vol.14, No.3, Sept 1974.

[8] British Standard 1377 (1990), Methods of test for soils for civil engineering purposes, part 1-8, London.

[9] C.P Lee, S.L Mohd, H. Kamaludin, M.N Bahari, and K. Rashidah, Stratographic Lexico of Malaysia, Geological Society of Malaysia, Kuala Lumpur, 2004

[10] A.B. Daud, "Clarification of Stratigraphic correlation and dating of Late Cainozoic alluvial units in Peninsular Malaysia", Bulletin of the Geological Society of Malaysia, Vol.61, pp 75-84, Dec 2015.

[11] Withlow, R. (2004), Basic Soil Mechanics, Prentice Hall Pearson Education, Singapore, Edition 4.

\section{PROFILES}

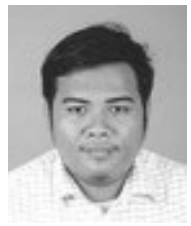

SYAHMIZZI IFWAT AZHARNIM obtained his Bachelor Engineering (HONS) Civil and Master of Science in Geotechnical Engineering from Universiti Teknologi MARA (UiTM), Malaysia in 2013 and 2015 respectively. Currently, he is a Senior Geotechnical Engineer in Minconsult Sdn Bhd (Multi-disciplinary International Consulting Company established on 1962) and involve in Geotechnical Design and Analysis of Deep and Shallow Foundation, Slope Stability, Deep Excavation Works and Retaining Wall System, Ground Improvement Method, etc. for various projects.

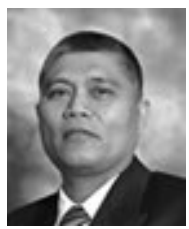

MOHD JAMALUDIN MD. NOOR is currently a senior lecturer of Universiti Teknologi MARA (UiTM), Malaysia. He received his B.Sc (HONS) Civil Engineering in 1984 from University College of Swansea Wales, United Kingdom, M.Sc Geotechnics in 1996 from Ohio University, U.S.A and Doctor of Philosophy (Ph.D) in 2006 from University of Sheffield, United Kingdom. He is active Author and Co-Author for a research which interest on Shear Strength behaviour of soils based on Curved Surface Shear Strength Model, Stability of Slope of Residual Soils subjected to Infiltration, Soil Settlement behaviour by concept of effective stress and shear strength interaction and many more. 